\title{
The stability of silage containing biological and chemical additives assessed using a Rusitec system
}

\author{
A. Potkański ${ }^{1,3}$, A. Cieślak ${ }^{1}$, M. Szumacher-Strabel ${ }^{1}$, S. Wylegała ${ }^{1}$, \\ K. Raczkowska-Werwińska ${ }^{1}$, A. Gubała ${ }^{1}$ and J. Kowalczyk ${ }^{2}$
}

\author{
${ }^{1}$ The August Cieszkowski Agricultural University of Poznań, \\ Department of Animal Nutrition and Feed Management \\ Wotyńska 33, 60-637 Poznań, Poland \\ ${ }^{2}$ The Kielanowski Institute of Animal Physiology and Nutrition, Polish Academy of Sciences \\ 05-110 Jabtonna, Poland
}

\begin{abstract}
Grass-clover silage was treated with biological (VTT) and chemical (KemiSile 2000) additives to asses their effects on silage fermentation, aerobic stability and rumen fermentation pattern in a Rusitec system. Sixty days after ensiling, basic parameters were determined in silages. The experimental material was then investigated using a Rusitec system. Each of the additives decreased $(\mathrm{P}<0.05)$ the ammonia level in rumen fluid after incubation. Both additives increased $(\mathrm{P}<0.01)$ the level of protozoa, which can be explained by a higher level of available nutrients. A higher isovalerate content was found in rumen fluid after fermentation, whereas the valerate content was lower when VTT was added to the ensiling material. The additives improved silage quality, but the biological preservative decreased its aerobic stability.
\end{abstract}

KEY WORDS: grass silage, Rusitec system, fermentation, inoculant

\section{INTRODUCTION}

Silage quality depends on the quality of the plant material at ensiling, type of fermentation, rate of $\mathrm{pH}$ decrease, moisture content and maintenance of anaerobic conditions. Air is detrimental to silage quality because it enables aerobic spoilage microorganisms to become active (Filya et al., 2004). To promote adequate fermentation patterns and thus proper animal production, lactic acid bacterial inoculants and chemical additives are commonly used. The aim of this study was to determine the effect of biological and chemical additives on aerobic stability, silage quality and rumen fermentation in vitro in a RUSITEC system (Rumen Simulation Technique).

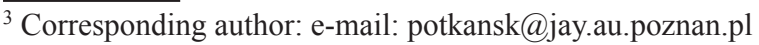




\section{MATERIAL AND METHODS}

In this experiment, silages were prepared from a grass-clover mixture in three barrels. The ensiling process lasted 60 days. The following additives were applied to fresh forage at the levels recommended by the manufacturer:

- control without additives

- biological (VTT; Lactobacillus plantarum E-78076)

- chemical (KemiSile 2000 composed of formic acid, ammonia formate, propionic acid and benzoic acid/ethyl benzoate).

Ensiled materials were sampled for chemical analysis on the 60 day. The silages were subjected to an aerobic stability test at room temperature for 7 days. To evaluate the effect of silages with and without additives on the rumen fermentation pattern, the in vitro study was carried out in a Rusitec system (Czerkawski and Breckenridge, 1977). The Rusitec had 3 L vessels: the 1, was filled with material from the barrel with control silage without additives, the 2, with KemiSile 2000 silage, and the 3, with VTT silage. The experiment lasted 10 days. On days 5-10, every vessel was sampled for analysis of $\mathrm{pH}$, ammonia nitrogen $\left(\mathrm{NH}_{3}-\mathrm{N}\right)$, volatile fatty acids and microorganism count (Table 2). The results were subjected to statistical analyses using SAS procedures (1996).

\section{RESULTS AND DISCUSSION}

Sixty days after ensiling, the silages treated with either biological or chemical additives improved their quality and had a lower $\mathrm{pH}$ but higher dry- and organic matter contents (Table 1). A lower concentration of acetate was also found, but the propionate level increased in the KemiSile 2000 silage, whereas it decreased in the silage with VTT, which is a source of propionic acid. The silages treated with either additive had a higher lactate concentration but lower

Table 1. Effect of silage additives on silage parameters $(n=3)$

\begin{tabular}{lccc}
\hline \multirow{2}{*}{ Item } & control & with KemiSile 2000 & with VTT \\
\hline pH & 3.92 & 3.72 & 3.59 \\
Dry matter, \% & 14.79 & 16.24 & 16.38 \\
Organic matter, \% & 12.86 & 14.18 & 14.35 \\
Ammonia, \% & 0.08 & 0.12 & 0.05 \\
Acetate, g/kg DM & 57.25 & 27.09 & 19.94 \\
Propionate, g/kg DM & 6.09 & 10.67 & 3.46 \\
Butyrate, g/kg DM & 0.90 & 0.41 & 0.41 \\
Lactate, g/kg DM & 58.82 & 66.08 & 101.32 \\
Reducing sugars, \% & 6.76 & 27.70 & 23.80 \\
ADF g/kg DM & 297.95 & 272.52 & 275.28 \\
NDF g/kg DM & 405.23 & 377.59 & 386.78 \\
\hline
\end{tabular}


NDF and ADF contents. Kung and Ranjit (2001) obtained similar results in silages treated with various chemical and biological additives, e.g., ones rich in Lactobacillus buchneri.

Untreated silage was aerobically stable for 7 days. The biological additive altered the fermentation pattern and increased oxidation processes, whereas the chemical additive had no effect on aerobic stability (Figure 1). The use of Lactobacillus plantarum should improve aerobic stability, e.g., by inhibition of yeast activity (Filya, 2003), but we obtained opposite results. The experiments of Kung et al. (2004) confirmed that buffered propionic acid-based products in some circumstances could improve aerobic stability.

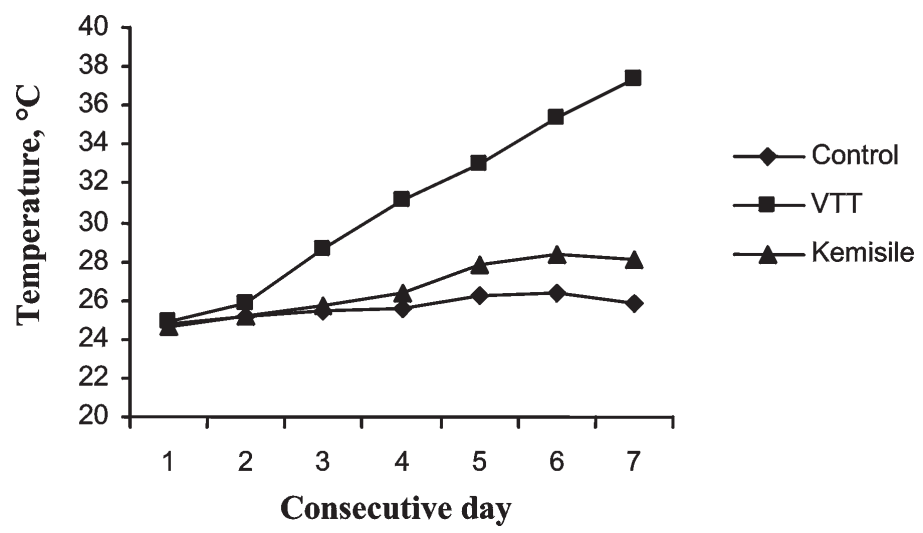

Figure 1. Results of the aerobic stability test (7 days) of silages with different additives

TABLE 2.

Effect of silage additives on basic rumen parameters in vitro $(\mathrm{n}=5)$

\begin{tabular}{lcccccc}
\hline Item & $\begin{array}{c}\text { Silage } \\
\text { control }\end{array}$ & SE & $\begin{array}{c}\text { Silage with } \\
\text { KemiSile 2000 }\end{array}$ & SE & $\begin{array}{c}\text { Silage with } \\
\text { VTT }\end{array}$ & SE \\
\hline $\begin{array}{l}\text { Rumen fluid properties } \\
\text { pH }\end{array}$ & 7.02 & 0.07 & 7.01 & 0.05 & 7.07 & 0.04 \\
ammonia, mmol/L & $6.30^{\mathrm{a}}$ & 0.36 & $4.21^{\mathrm{b}}$ & 0.27 & $5.40^{\mathrm{ab}}$ & 0.38 \\
acetate (A) & 54.27 & 0.45 & 56.49 & 0.54 & 55.44 & 0.83 \\
propionate (P) & 21.18 & 0.35 & 20.04 & 1.47 & 23.68 & 0.29 \\
butyrate & 10.79 & 0.17 & 11.22 & 0.15 & 10.74 & 0.42 \\
izobutyrate & 3.37 & 0.12 & 2.80 & 0.56 & 3.12 & 0.23 \\
valerate & $5.94^{\mathrm{a}}$ & 0.56 & $5.54^{\mathrm{ab}}$ & 1.13 & $3.26^{\mathrm{b}}$ & 0.65 \\
isovalerate & $4.45^{\mathrm{a}}$ & 0.38 & $3.91^{\mathrm{b}}$ & 0.32 & $3.76^{\mathrm{b}}$ & 0.16 \\
A/P & 2.57 & 0.05 & 2.90 & 0.28 & 2.34 & 0.03 \\
Rumen fluid microbial counts & & & & & \\
bacteria, 10 $\mathrm{ml}^{-1}$ & 3.36 & 0.55 & 3.92 & 0.75 & 2.44 & 0.36 \\
protozoa, 10 $\mathrm{ml}^{-1}$ & $0.69^{\mathrm{B}}$ & 0.43 & $2.78^{\mathrm{A}}$ & 0.35 & $2.17^{\mathrm{A}}$ & 0.63 \\
DMD, \% & 75.31 & 2.26 & 75.14 & 2.42 & 76.81 & 3.54 \\
\hline
\end{tabular}

means with the same letter are not significantly different; ${ }^{\mathrm{a}, \mathrm{b}}$ - $\mathrm{P} \leq 0.05$; ${ }^{\mathrm{A}, \mathrm{B}}$ - $\mathrm{P} \leq 0.01$ 
In the part of the experiment with the use of the Rusitec system (Table 2), ammonia decreased $(\mathrm{P}<0.05)$ in both experimental groups whereas the $\mathrm{pH}$ was about 7.0 in all groups. Both used additives increased $(\mathrm{P}<0.01)$ the protozoa level, which can be explained by the higher level of available nutrients. The silages with the additives had higher isovalerate contents. A lower valerate concentration was observed in VTT silage in comparison with the control group.

\section{CONCLUSIONS}

The additives used in the experiment improved silage quality, but under our conditions, the biological preservative based on Lactobacillus plantarum, decreased the aerobic stability of the prepared silage. This could have been caused by the relatively high temperature of the test room, which exceeded $23^{\circ} \mathrm{C}$.

\section{RERERENCES}

Czerkawski, J.W., Beckenridge G., 1977. Design and development of long-term rumen simulation technique (RUSITEC). Brit. J. Nutr. 38, 371-384

Filya I., 2003. The effect of Lactobacillus buchneri and Lactobacillus plantarum on the fermentation, aerobic stability, and ruminal degradability of low dry matter corn and sorghum silages. J. Dairy Sci. 86, 3575-3581

Filya I., Sucu E., Karabulut A., 2004. The effect of Propionibacterium acidipropionici, with or without Lactobacillus plantarum, on the fermentation and aerobic stability of wheat, sorghum and maize silages. J. Appl. Microbiol. 97, 818-126

Kung Jr. L., Myers C.L., Neylon J.M., Taylor C.C., Lazartic J., Mills J.A., Whiter A.G., 2004. The effects of buffered propionic acid-based additives alone or combined with microbial inoculation on the fermentation of high moisture corn and whole-crop barley. J. Dairy Sci. 87, 1310-1316

Kung Jr. L., Ranjit N.K., 2001. The effect of Lactobacillus buchneri and other additives on the fermentation and aerobic stability of barley silage. J. Dairy Sci. 84, 1149-1155

$\mathrm{SAS}^{\circledR}, 1996 . \mathrm{SAS} / \mathrm{STAT}$ Users Guide (Release 6.12). SAS Institute Inc., Cary, NC

\section{STRESZCZENIE}

Stabilność kiszonki z traw i koniczyny z biologicznymi i chemicznymi dodatkami oraz parametry żwacza przy wykorzystaniu systemu Rusitec

W przeprowadzonych badaniach określono wpływ dodatków kiszonkarskich: biologicznego (VTT) i chemicznego (KemiSile 2000) na jakość i stabilność tlenową kiszonki trawiasto-koniczynowej zakiszanej w beczkach. Dodatki poprawiły jakość kiszonki, lecz dodatek biologiczny obniżył stabilność tlenową zakiszanego materiału. Stwierdzono spadek $(\mathrm{P}<0,05)$ poziomu amoniaku oraz wzrost $(\mathrm{P}<0,01)$ liczebności pierwotniaków w płynie żwacza po inkubacji w Rusitecu. Poziom kwasu izowalerianowego był wyższy, a kwasu walerianowego niższy w płynie żwacza po fermentacji kiszonki z dodatkiem VTT. 